\title{
Budesonide and terbutaline or terbutaline alone in children with mild asthma: effects on bronchial hyperresponsiveness and diurnal variation in peak flow
}

\author{
H J Waalkens, J Gerritsen, G H Koëter, F H Krouwels, W M C van Aalderen, K Knol
}

\begin{abstract}
The effects of treatment with budesonide (200 $\mu \mathrm{g}$ twice daily) and terbutaline (500 $\mu \mathrm{g}$ four times daily) has been compared with the effects of placebo and terbutaline in 27 children with mild asthma, aged 714 years, in a double blind, randomised placebo controlled study over eight weeks. Bronchial responsiveness $\mathbf{( P C}_{20}$ histamine), lung function, the amplitude of diurnal variation in peak expiratory flow (PEF), and symptom scores were measured. Baseline FEV $_{1}$ was over $70 \%$ predicted and $\mathbf{P C}_{20}$ histamine less than 8 $\mathrm{mg} / \mathrm{ml}$. Twelve children were treated with budesonide and terbutaline and 15 with placebo and terbutaline. After four and eight weeks of treatment the change in $\mathbf{P C}_{20}$ was significantly greater after budesonide and terbutaline than after terbutaline alone by $2 \cdot 1(95 \%$ CI $0 \cdot 5-3 \cdot 8)$ and $1.3(95 \%$ CI $0 \cdot 1-2 \cdot 5)$ doubling doses respectively. Mean $\mathrm{FEV}_{1}$ did not change in either group. The change in afternoon and nocturnal PEF was significantly greater after budesonide and terbutaline than after terbutaline alone. The amplitude of diurnal variation in PEF did not change significantly in either group. Peak flow reversibility decreased in the budesonide group. There were no differences between treatments for cough and dyspnoea, but wheeze improved in the budesonide group. The children with mild asthma treated with budesonide and terbutaline showed improvement in bronchial responsiveness, afternoon and nocturnal PEF, and symptoms of wheeze and a fall in peak flow reversibility by comparison with those who received terbutaline alone.
\end{abstract}

Bronchial hyperresponsiveness, a common feature of asthma in adults and children, ${ }^{1}$ can be assessed by inhalation provocation tests with histamine or methacholine. Viral infection, ozone exposure, and a late asthmatic reaction after allergen challenge may induce an increase in bronchial responsiveness, ${ }^{2-4}$ suggesting that inflammatory processes are important in its development. Maintenance treatment with anti-inflammatory drugs, such as budesonide and beclomethasone, reduces bronchial responsiveness in children and adults with asthma, and this has been ascribed to a reduction in airway inflammation. ${ }^{56}$
Bronchial smooth muscle contraction also contributes to bronchoconstriction and is often treated by beta ${ }_{2}$ agonists. An increased amplitude in the diurnal variation in measures of airflow is seen in asthma and is thought to reflect the severity of the disease. ${ }^{7}$ We have investigated whether the addition of budesonide to maintenance treatment with terbutaline can improve respiratory symptoms, pulmonary function, bronchodilator response, bronchial responsiveness, and the amplitude of diurnal variation in peak flow (PEF) in children with mild asthma. The study had a parallel group double blind design.

\section{Methods}

PATIENTS

Thirty two asthmatic children aged 7-14 (mean $10 \cdot 3$ ) years were included. All had a history of episodic shortness of breath or wheeze or both, bronchial hyperresponsiveness with a provocative concentration of histamine causing a $20 \%$ fall in $\mathrm{FEV}_{1}\left(\mathrm{PC}_{20}\right)$ of $8 \mathrm{mg} / \mathrm{ml}$ or less, and a positive skin test response or specific IgE against one or more common allergens.

All children had mild symptoms that were controlled by an inhaled beta ${ }_{2}$ agonist or sodium cromoglycate or both. None of the children had been treated with an inhaled corticosteroid in the preceding six months or was taking an oral corticosteroid regularly. None had a history to suggest a viral or bacterial respiratory tract infection or an exacerbation of asthma in the month before the study. Children with pollen allergies were not studied during the pollen season. The children had to be capable of performing reproducible pulmonary function tests. Baseline $\mathrm{FEV}_{1}$, measured during the selection period, had to be above $70 \%$ of the predicted value. ${ }^{8}$ Before entering the study the children discontinued their maintenance treatment for at least two weeks. They were allowed to use a beta ${ }_{2}$ agonist only, on an "if needed" basis to control their symptoms.

The study was approved by the hospital medical ethics committee and informed consent was obtained from both the children and their parents.

\section{STUDY DESIGN}

In a double blind design the children were randomly allocated to one of two parallel groups on their first visit. During an initial single blind run in period of two weeks all 
children received terbutaline (500 $\mu \mathrm{g}$ four times daily) and placebo (twice daily). After the run in period the inclusion criteria were checked again and for the next eight weeks the children received either budesonide $(200 \mu \mathrm{g}$ twice daily) and terbutaline (500 $\mu \mathrm{g}$ four times daily) or placebo and terbutaline ( $500 \mu \mathrm{g}$ four times daily). Budesonide and placebo were administered with a $750 \mathrm{ml}$ spacer device (Nebuhaler) and terbutaline with a smaller spacer device. When needed, up to four additional terbutaline puffs $(250 \mu \mathrm{g})$ were allowed a day.

The children recorded daily PEF (mini Wright, best of three attempts) at 8 am and 4 $\mathrm{pm}$, before and 10 minutes after inhaling $500 \mu \mathrm{g}$ terbutaline, during the run in period and during weeks $3,4,7$, and 8 of the double blind treatment phase. The children were woken by their parents at 4 am twice in the week before each visit to the outpatient department for measurement of nocturnal PEF. Cough, wheeze, and dyspnoea were recorded daily on a $0-3$ scale $(0=$ no and $3=$ severe symptoms $)$.

$\mathrm{FEV}_{1}$ and $\mathrm{PC}_{20}$ histamine were measured before and after the run in period and after four and eight weeks of treatment. Patients' compliance was assessed by weighing the metered dose inhalers before and after use.

\section{LUNG FUNCTION AND INHALATION PROVOCATION TESTS}

Measurements were carried out 12-16 hours after the last drug inhalation and were always performed in each subject at the same time of the day. Forced expiratory volume in one second $\left(\mathrm{FEV}_{1}\right)$ and forced vital capacity (FVC) were determined with a water sealed spirometer (Lode, Groningen, The Netherlands). The best of three reproducible efforts was used for data analysis.

The histamine provocation was performed according to the Cockcroft method..$^{9}$ The solutions were nebulised with a gauged DeVilbiss 646 nebuliser (output $0.13 \mathrm{ml} / \mathrm{min}$ ) attached to an inspiratory-expiratory valve box. After inhalation of isotonic saline, phosphate buffered histamine was inhaled in doubling concentrations from 0.03 to $16 \mathrm{mg} / \mathrm{ml}$. Each dose was inhaled for two minutes at five minute intervals with tidal breathing while the nose was clipped, until there was a fall in $\mathrm{FEV}_{1}$ of $20 \%$ from baseline $F E V_{1}$ or until the maximum concentration of histamine had been inhaled. The
$\mathrm{PC}_{20}$ histamine was calculated from a log doseresponse curve.

After a time interval of at least 30 minutes and spontaneous recovery of $\mathrm{FEV}_{1}$ to at least $90 \%$ of baseline $\mathrm{FEV}_{1} 500 \mu \mathrm{g}$ terbutaline was administered. Reversibility ( $\Delta \mathrm{FEV}_{1} \%$ pred) was calculated as the difference between baseline $\mathrm{FEV}_{1}$ before histamine challenge and $\mathrm{FEV}_{1} 10$ minutes after inhalation of $500 \mu \mathrm{g}$ terbutaline.

The amplitude of diurnal variation in PEF over the day was calculated as the difference between the lowest and the highest prebronchodilator PEF each day expressed as a percentage of mean PEF. Response to a bronchodilator (PEF reversibility) was calculated as the difference between the lowest PEF (usually prebronchodilator PEF) and the highest PEF (usually postbronchodilator PEF) each day expressed as a percentage of mean PEF.

\section{STATISTICAL ANALYSIS}

The $\mathrm{PC}_{20}$ histamine values were log transformed for analysis and are expressed as geometric mean values. $\mathrm{FEV}_{1}$ was expressed as a percentage of the predicted value. Mean PEF and symptom scores were calculated over 14 consecutive days in the run in period, and for weeks $3,4,7$, and 8 of treatment. The data are expressed as means with standard errors in parentheses unless otherwise dated. Student's $t$ test for unpaired data and Fisher's exact test were used to compare the two treatment groups on entry to the study. Individual changes in $\mathrm{FEV}_{1}, \mathrm{PC}_{20}$, mean peak flow values, and symptom scores were analysed by paired Student's $t$ test. Comparison of the changes between the two treatment groups were calculated by means of Wilcoxon's signed rank test or Student's $t$ test for unpaired observations. $\mathrm{FEV}_{1}$ and $\mathrm{PC}_{20}$ histamine values at visits 3 and 4 were compared with the data just before the double blind treatment period (visit 2). Mean PEF recordings and symptom scores measured in weeks $3+4$ and weeks $7+8$ of treatment were compared with the values in the run in period. We considered a p value of 0.05 to be statistically significant. Power analysis showed a probability of $80 \%$ of obtaining a significant result if the difference between $\mathrm{PC}_{20}$ histamine in the two groups was 1.5 doubling concentrations, on the assumption of a standard deviation of 1.5 doubling dose steps.

\section{Results}

Thirty two children were included in the study. Five children (three in the budesonide group and two in the terbutaline only group) were withdrawn before entering the treatment period for the following reasons: $F E V_{1}$ fell below $70 \%$ predicted (one child), $\mathrm{PC}_{20}$ histamine rose above $8 \mathrm{mg} / \mathrm{ml}$ (one), non-compliance (one), and asthma symptoms increased (two). The mean $\mathrm{PC}_{20}$ and $\mathrm{FEV}_{1} \%$ predicted of those withdrawn did not differ significantly from values in patients who completed the study.

Of the 27 children completing the study, 12 children were treated with budesonide and
Prior use of cromoglycate (n) $\mathrm{FEV}_{1}(\%$ pred $)$

VC $(\%$ pred $)$

Reversibility $(\triangle \mathrm{FEV}, \%$ pred)

$\mathrm{PC}_{20}(\mathrm{mg} / \mathrm{ml})^{\star}$

*Geometric mean $(95 \% \mathrm{CI})$

$\mathrm{FEV}_{1}$ - forced expiratory volume in one second; VC-vital capacity; $\mathrm{PC}_{20}$-provocative concentration of histamine causing a $20 \%$ fall in FEV,

$13 / 2$
$9 \cdot 8(0 \cdot 5)$
12
$92 \cdot 5(2 \cdot 9)$
$94 \cdot 0(2 \cdot 8)$
$6 \cdot 8(2 \cdot 0)$
$0 \cdot 89(0 \cdot 42-1 \cdot 9)$


Table $2 F E V_{1}$, change in $F E V, \%$ predicted with terbutaline and $P C_{20}$ histamine in the two groups at 0, 4 and 8 weeks (mean (95\% CI))

\begin{tabular}{|c|c|c|c|}
\hline Week: & 0 & 4 & 8 \\
\hline \multicolumn{4}{|l|}{ BUDESONIDE AND TERBUTALINE } \\
\hline FEV, \% pred & $\begin{array}{l}93 \cdot 0 \\
(84-102)\end{array}$ & $\begin{array}{l}90 \cdot 6 \\
(78-103)\end{array}$ & $\begin{array}{l}93 \cdot 3 \\
(87-101)\end{array}$ \\
\hline Reversibility ( $\triangle \mathrm{FEV}, \%$ pred) & $\begin{array}{l}5 \cdot 2 \\
(2 \cdot 7-5 \cdot 7)\end{array}$ & $\begin{array}{l}6 \cdot 6 \\
(2 \cdot 4-10 \cdot 8)\end{array}$ & $\begin{array}{l}6 \cdot 8 \\
(2 \cdot 8-10 \cdot 8)\end{array}$ \\
\hline $\mathrm{PC}_{20}$ histamine $(\mathrm{mg} / \mathrm{ml})$ & $\begin{array}{l}0 \cdot 30 \\
(0 \cdot 14-0.62)\end{array}$ & $\begin{array}{l}0.90 \\
(0.43-1 \cdot 86)\end{array}$ & $\begin{array}{l}0.68 \\
(0.34-1 \cdot 35)\end{array}$ \\
\hline \multicolumn{4}{|l|}{ PLACEBO AND TERBUTALINE } \\
\hline FEV $_{1} \%$ pred & $\begin{array}{l}94 \cdot 0 \\
(88 \cdot 2-99 \cdot 8)\end{array}$ & $\begin{array}{l}93.9 \\
(88 \cdot 5-99 \cdot 3)\end{array}$ & $\begin{array}{l}90 \cdot 2 \\
(83 \cdot 9-96 \cdot 5)\end{array}$ \\
\hline Reversibility $\left(\triangle \mathrm{FEV}_{1} \%\right.$ pred $)$ & $\begin{array}{l}6 \cdot 1 \\
(3 \cdot 5-8 \cdot 8)\end{array}$ & $\begin{array}{l}7 \cdot 8 \\
(4 \cdot 4-11 \cdot 1)\end{array}$ & $\begin{array}{l}8 \cdot 7 \\
(4 \cdot 4-13 \cdot 0)\end{array}$ \\
\hline $\mathrm{PC}_{20}$ histamine $(\mathrm{mg} / \mathrm{ml})$ & $\begin{array}{l}0.82 \\
(0.51-1 \cdot 29)\end{array}$ & $\begin{array}{l}0.58 \\
(0.23-1.45)\end{array}$ & $\begin{array}{l}0.75 \\
(0 \cdot 49-1 \cdot 12)\end{array}$ \\
\hline
\end{tabular}

Abbreviations as in table 1.

terbutaline and 15 with terbutaline and placebo. On entering the study (visit 1) the two groups were similar with respect to age, sex, respiratory symptoms, $\mathrm{FEV}_{1}, \mathrm{FVC}$, daily $\mathrm{PEF}$ recordings, $\mathrm{PC}_{20}$ histamine, reversibility of bronchial obstruction, and prior use of sodium cromoglycate. The characteristics of the children who completed the study are presented in table 1 .

\section{BRONCHIAL RESPONSIVENESS}

Geometric mean $\mathrm{PC}_{20}$ histamine values are presented in table $2 . \mathrm{PC}_{20}$ histamine increased significantly after treatment with budesonide plus terbutaline $(p<0.05)$ and decreased slightly and non-significantly after placebo plus terbutaline. After four and eight weeks of treatment the change in $\mathrm{PC}_{20}$ was significantly greater after budesonide and terbutaline than after terbutaline alone. The mean difference was $2 \cdot 1(95 \%$ CI $0 \cdot 5-3 \cdot 8)$ and $1 \cdot 3(95 \%$ CI $0 \cdot 1-2 \cdot 5)$ doubling doses respectively $(\mathrm{p}<0.05)$ (figure).

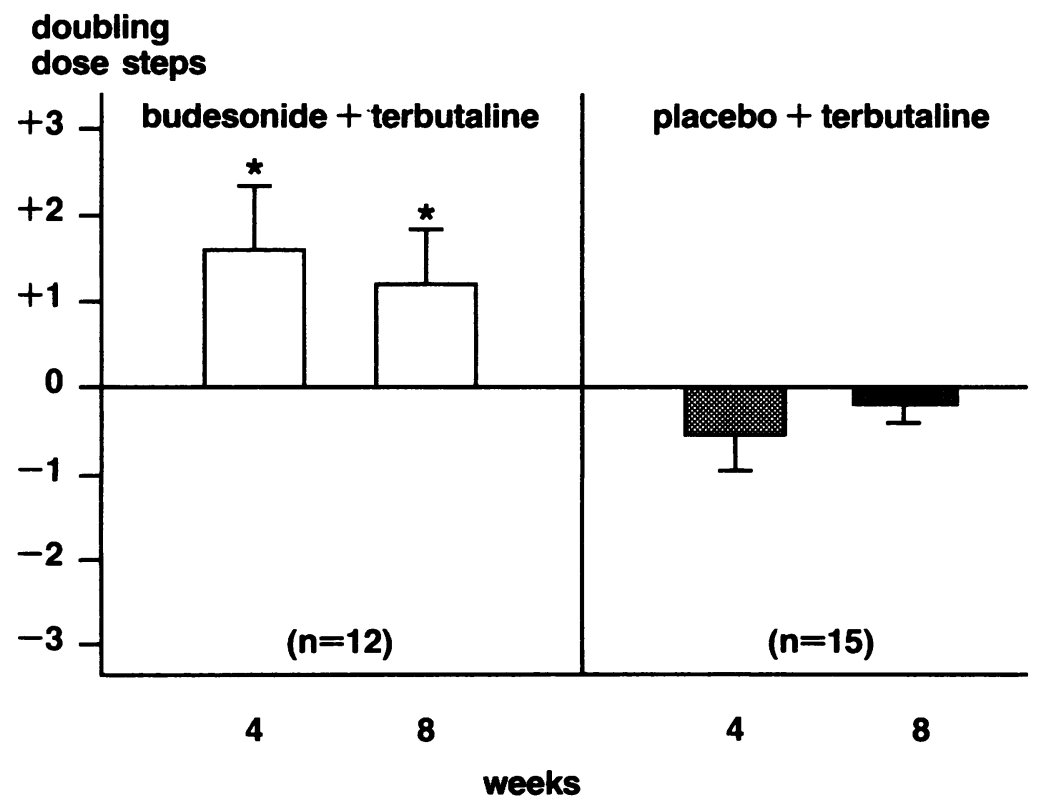

Change from baseline in $P C_{20}$ histamine (doubling doses) after four and eight weeks of treatment with budesonide and terbutaline or terbutaline only. ${ }^{\star} p<0.05$ : change from run in budesonide group versus change from run in terbutaline only group.
FEV $_{1}$ MEASUREMENTS AND CHANGE IN FEV 1 AFTER TERBUTALINE

Mean $F E V_{1}$ remained unchanged in both treatment groups (table 2) and there were no significant differences in change in $\mathrm{FEV}_{1}$ between the two groups. The change in FEV after terbutaline ( $\Delta \mathrm{FEV}_{1} \%$ pred) did not show any significant differences between the two groups (table 2).

PEAK FLOW VALUES

Morning peak flow rate increased significantly in both treatment groups $(\mathrm{p}<0.05)$; the difference between the two groups was not significant, however. Afternoon PEF increased significantly only in the budesonide group. The change in afternoon and nocturnal peak flow was significantly greater in the budesonide group than in the terbutaline only group. Mean PEF values before and after bronchodilatation are presented in table 3.

\section{AMPLITUDE OF DIURNAL VARIATION IN PEAK}

FLOW RATE

Change in the amplitude of diurnal variation in PEF did not differ significantly between the two groups. In the budesonide group the amplitude of diurnal variation in PEF fell from $11.7 \%$ (run in period) to $8.1 \%$ (weeks $7+8$ ) and in the terbutaline only group from $11.6 \%$ to $9.0 \%$. The decrease in peak flow reversibility was significantly greater after budesonide and terbutaline than after terbutaline alone-from $15.8 \%$ (run in) to $10.5 \%$ (in weeks $7+8$ ) in the budesonide group and from $17.5 \%$ to $15.4 \%$ in the terbutaline only group.

\section{SYMPTOM SCORES}

Mean values for symptom scores of wheeze, dyspnoea, and cough were low throughout the study in both groups. There were no significant differences in symptom scores for cough and dyspnoea between treatment groups. In the budesonide group the mean (SD) cough score changed slightly from $0.26(0.34)$ in the run in period to $0.09(0.14)$ in weeks $7+8$ and from $0.35(0.45)$ to $0.17(0.36)$ in the terbutaline only group. The mean score for dyspnoea changed from $0.12(0.20)$ to $0.02(0.06)$ in the budesonide group and from $0 \cdot 27(0.38)$ to $0 \cdot 10(0 \cdot 17)$ in the terbutaline only group. Only wheeze decreased significantly, from a mean score of $0.11(0.12)$ in the run in period to $0.01(0.02)$ in weeks $7+8$ in the budesonide group, remaining unchanged in the terbutaline only group $(0 \cdot 12$ $(0 \cdot 16)$ in the run in period and $0.12(0.25)$ in weeks $7+8)$. The difference between the two treatments was significant $(p<0.05)$.

PATIENTS' COMPLIANCE

In the run in period the mean number of inhalations of placebo $(2.2$ puffs/day $)$ did not differ significantly from the prescribed two inhalations in either group. During the double blind treatment budesonide use was 2.5 puffs a day in the first month and 1.9 in the second, and placebo use 2.0 and 2.3 puffs a day, none of these figures differing significantly from the two inhalations prescribed. In the terbutaline only group terbutaline use changed from $7 \cdot 3$ puffs a 
Table 3 Mean (SD) peak expiratory flow (PEF) before and 10 minutes after bronchodilatation

\begin{tabular}{|c|c|c|c|c|}
\hline & & \multicolumn{3}{|c|}{ Peak expiratory flow (l/min) } \\
\hline & & Run in & Weeks $3+4$ & Weeks $7+8$ \\
\hline \multicolumn{5}{|l|}{ Morning PEF } \\
\hline $\begin{array}{l}\text { Budesonide }+ \text { terbutaline } \\
\text { Placebo }+ \text { terbutaline }\end{array}$ & $\begin{array}{l}\text { Before } \\
\text { After } \\
\text { Before } \\
\text { After }\end{array}$ & $\begin{array}{l}329(87) \\
356(90) \\
325(76) \\
359(83)\end{array}$ & $\begin{array}{l}351(93)^{\star} \\
368(94) \\
329(82) \\
360(83)\end{array}$ & $\begin{array}{l}359(88)^{\star} \\
374(94)^{\star} \\
339(70)^{\star \star} \\
369(79)^{\star \star}\end{array}$ \\
\hline \multicolumn{5}{|l|}{ Afternoon PEF } \\
\hline $\begin{array}{l}\text { Budesonide }+ \text { terbutaline } \\
\text { Placebo }+ \text { terbutaline }\end{array}$ & $\begin{array}{l}\text { Before } \\
\text { After } \\
\text { Before } \\
\text { After }\end{array}$ & $\begin{array}{l}359(92) \\
370(93) \\
353(90) \\
373(88)\end{array}$ & $\begin{array}{l}374(96)^{\star} \\
385(96)^{\star \dagger} \\
350(84) \\
372(86)\end{array}$ & $\begin{array}{l}382(97)^{\star \star \dagger} \\
391(99)^{\star \star \dagger} \\
357(80) \\
380(85)^{\star \star}\end{array}$ \\
\hline $\begin{array}{l}\text { Nocturnal PEF } \\
\text { Budesonide + terbutaline } \\
\text { Placebo + terbutaline }\end{array}$ & & $\begin{array}{l}328(86) \\
310(81)\end{array}$ & $\begin{array}{l}354(100) \\
303(100)\end{array}$ & $\begin{array}{l}355(44) \dagger \\
299(87)\end{array}$ \\
\hline
\end{tabular}

${ }^{\star} \mathrm{p}<0.05 ;{ }^{\star \star} \mathrm{p}<0.01$ (versus run in period).

$t_{\mathrm{p}}<0.05$ (change from run in budesonide and terbutaline group versus change from run in terbutaline only group).

day in the run in period to $6 \cdot 8$ in the first and $7 \cdot 5$ in the second month of treatment (NS). In the budesonide group terbutaline use decreased significantly from 6.7 puffs a day in the run in period to 5.7 in the first and 5.7 in the second month $(p<0.05)$. In the second month of treatment terbutaline use was lower in the budesonide group than in the terbutaline only group $(\mathrm{p}<0.05)$.

\section{Discussion}

In the present study we investigated the effect of adding budesonide to regular treatment with terbutaline. We observed a decrease in bronchial responsiveness with budesonide and terbutaline treatment by comparison with terbutaline alone. Treatment of bronchial hyperresponsiveness may have consequences for the outcome of childhood asthma, as children with a high degree of bronchial responsiveness are at risk of continuing to have respiratory symptoms in adult life. ${ }^{10}$ In this relatively short study all children remained hyperresponsive and we cannot be sure whether the observed changes in bronchial hyperresponsiveness are of clinical importance. Most studies, in children and in adults with asthma, have shown a modest decrease in bronchial hyperresponsiveness during treatment with inhaled corticosteroids. ${ }^{5611}$ The exact mechanism of this process is still uncertain. Several studies have suggested that inflammatory processes contribute to bronchial hyperresponsiveness. Extensive inflammatory changes have been found in bronchial biopsy specimens from patients with mild asthma only, ${ }^{12-14}$ though a recent study reported no significant differences between bronchial biopsy specimens from patients with asthma and healthy controls. ${ }^{15}$ Corticosteroids are known to inhibit virtually every stage in the inflammatory response. ${ }^{16}$ The observation that extensive inflammation may be found in biopsy material from patients with mild asthma and the fact that corticosteroids can suppress inflammatory processes suggest that inhaled corticosteroids may have a place in the treatment of patients with mild symptoms. Long term studies are needed to establish the effect of treatment with inhaled corticosteroids on the outcome of childhood asthma.
There was a slight increase in bronchial responsiveness to histamine after four weeks' treatment with terbutaline alone but not after eight weeks' treatment. A few studies have focused on the relation between the use of beta agonists and bronchial responsiveness. Peel and Gibson found no significant difference in $\mathrm{PC}_{20}$ histamine measured before and four weeks after treatment with salbutamol. ${ }^{17}$ Kraan et $a l^{6}$ showed a slight but significant increase in bronchial responsiveness to histamine after two weeks' inhaled terbutaline, which was not significant at four weeks. These findings were confirmed by Kerrebijn and coworkers ${ }^{5}$ and Vathenen and associates, ${ }^{18}$ and more recently by Sears et al after regular treatment with fenoterol for six months. ${ }^{19}$ The mechanisms responsible for the increased bronchial responsiveness induced by beta agonists are still unknown. Some studies suggest that the changes could be caused by desensitisation of beta receptors, ${ }^{618}$ though a recent report showed increased bronchial responsiveness after long term inhaled salbutamol but no evidence of subsensitisation to beta agonists. ${ }^{20}$ Further studies are needed to clarify the action of beta agonists on bronchial responsiveness.

We found no significant improvement in $\mathrm{FEV}_{1}$ in either treatment group, which was not unexpected as we studied only children with mild or no bronchial obstruction. Other studies have shown an increase in the $\mathrm{FEV}_{1}$ in asthmatic patients during treatment with inhaled corticosteroids. ${ }^{5611}$

Change in $\mathrm{FEV}_{1}$ in response to a beta agonist did not alter in either group, in agreement with previous findings. ${ }^{21}$ The response to these drugs has been shown to be additive, ${ }^{22}$ although intravenous corticosteroid administration may restore the response to beta agonists in patients with acute severe asthma who were unresponsive to beta agonists. ${ }^{2324}$

In contrast to $\mathrm{FEV}_{1}$, we observed a consistent improvement in morning PEF in both groups and in afternoon PEF in the budesonide group. The reason why PEF increased in the budesonide group but not $F E V_{1}$ is probably that PEF was recorded a few times a day while the patient was taking medication whereas $\mathrm{FEV}_{1}$ was measured at the outpatient visit 1216 hours after the last dose of treatment.

The increase in nocturnal PEF was sig- 
nificantly greater in the budesonide group than in the terbutaline only group. Nocturnal and early morning dyspnoea are common symptoms in children and adults with asthma ${ }^{25}$; the mechanism remains uncertain. ${ }^{26}$ Inhaled beta agonists reduce morning dips in PEF, and inhaled corticosteroids produce further improvement. ${ }^{27}$ Dahl et al showed that inhaled budesonide ( $200 \mu \mathrm{g}$ twice daily) is as effective as sustained release terbutaline $(10 \mathrm{mg}$ twice daily) in controlling nocturnal asthma and that the combination was even better..$^{28}$

Airflow obstruction has a circadian rhythm with peak values at $4 \mathrm{pm}$ and trough values at 4 am in both asthmatic and normal children. ${ }^{729}$ The amplitude of the diurnal variation in PEF is higher in asthmatic patients than in normal subjects and has been shown to fall during treatment with inhaled corticosteroids ${ }^{6}$ and increase after their withdrawal. ${ }^{3031}$ The amplitude of diurnal variation in PEF was low in both groups in our study and there were no significant differences in the changes between the two groups. This again may be because the children had little or no bronchial obstruction, or possibly it is due in part to the terbutaline given in the run in period. ${ }^{32}$ Although some investigators include postbronchodilator values to express amplitude of diurnal variation in PEF, ${ }^{33}$ this seems to us to reflect diurnal variation in PEF less accurately, because it also includes the peak flow response to a bronchodilator. Studies that include postbronchodilator PEF values in the calculation of PEF variation are difficult to compare as they differ with regard to the time of measuring postbronchodilator PEF and the type and dose of bronchodilating drug. When postbronchodilating PEF values were included in our analysis, we found that peak flow reversibility decreased significantly in the budesonide group by comparison with the terbutaline only group. We have no plausible explanation for the difference in the effects of budesonide on PEF variation and $P E F$ reversibility.

We conclude that in children with mild asthma and increased bronchial responsiveness treatment with budesonide in addition to regular treatment with inhaled terbutaline over eight weeks leads to an improvement in bronchial responsiveness, an increase in afternoon and nocturnal PEF values, and a decrease in peak flow reversibility and symptoms of wheeze.

We thank the patients and parents for their cooperation and $\mathrm{Mr}$ M Boorsma for his comments and statistical assistance. The study was supported by Astra/Draco.

1 Boushey HA, Holtzmann MJ, Sheller JR, Nadel JA. Bronchial hyperreactivity. Am Rev Respir Dis 1980; 121:389-413.

2 Empey DW, Laitinen LA, Jacobs L, Gold WM, Nadel JA. Mechanisms of bronchial hyperreactivity in normal subjects after upper respiratory tract infections. Am Rev subjects after upper respira
Respir Dis 1976;113:131-9.

3 Dimeo MJ, Glenn MG, Holtzman MJ, Sheller JR, Nadel JA, Boushey HA. Threshold concentration of ozone causing an increase in bronchial reactivity in humans and adaptation with repeated exposures. Am Rev Respir Dis 1981;124:245-8.

4 Cockcroft DW, Ruffin RE, Dolovich J, Hargreave FE. Allergen-induced increase in non-allergic bronchial reactivity. Clin Allergy 1977;7:503-13.

5 Kerrebijn KF, van Essen-Zandvliet EEM, Neijens HJ. Effect of long-term treatment with inhaled corticosteroids and beta-agonists on the bronchial responsiveness in children with asthma. J Allergy Clin Immunol 1987; 79:653-9.

6 Kraan J, Koëter GH, vd Mark ThW, Sluiter HJ, de Vries K. Changes in bronchial hyperreactivity induced by 4 weeks of treatment with antiasthmatic drugs in patients with allergic asthma: a comparison between budesonide and terbutaline. J Allergy Clin Immunol 1985;76:628-36.

7 Hetzel MR, Clarck TJH. Comparison of normal and asthmatic circadian rhythms in peak expiratory flow rate. Thorax 1980;35:732-8.

8 Zapletal A, Samanek M, Paul T. Lung function in children and adolescents. Methods, reference values. In: Zapletal A, ed. Progress in respiration research 1987;22:114-218.

9 Cockcroft DW, Killian DN, Mellon JJA, Hargreave FE. Bronchial reactivity to inhaled histamine: a method and clinical survey. Clin Allergy 1977;7:235-43.

10 Gerritsen J, Koëter GH, Postma DS, Schouten JP, Knol K. Prognosis of asthma from childhood to adulthood. $A m$ Rev Respir Dis 1989;140:1325-30.

11 Molema J, van Herwaarden CLA, Folgering HThM. Effects of long-term treatment with inhaled cromoglycate and budesonide on bronchial hyperresponsiveness in patients with allergic asthma. Eur Respir J 1989;2:308-16.

12 Laitinen LA, Heino M, Laitinen A, Kava T, Haahtela T. Damage of the airway epithelium and bronchial reactivity in patients with asthma. Am Rev Respir Dis 1985;131: in patients

13 Beasley R, Roche WR, Roberts JA, Holgate ST. Cellular events in the bronchi in mild asthma and after bronchial provocation. Am Rev Respir Dis 1989;139:806-17.

14 Jeffery PK, Wardlaw AJ, Nelson FC, Collins JV, Kay AB. Bronchial biopsies in asthma. An ultrastructural, quantitative study and correlation with hyperreactivity. $\mathrm{Am}$ Rev Respir Dis 1989;140:1745-53.

15 Lozewicz S, Wells C, Gomez E, et al. Morphological integrity of the bronchial epithelium in mild asthma. Thorax 1990;45:12-5.

16 Barnes PJ. New concepts in the pathogenesis of bronchial hyperresponsiveness and asthma. J Allergy Clin Immunol 1989;83:1013-26.

17 Peel ET, Gibson GJ. Effects of long-term inhaled salbutamol therapy on the provocation of asthma by histamine. Am Rev Respir Dis 1980;121:973-8.

18 Vathenen AS, Knox AJ, Higgins BG, Britton JR, Tattersfield AE. Rebound increase in bronchial responsiveness after treatment with inhaled terbutaline. Lancet 1988; i:554-7.

19 Sears MR, Taylor DR, Print CG. Regular inhaled betaagonist treatment in bronchial asthma. Lancet 1990; 336:1391-6.

20 Van Schayck CP, Graafsma SJ, Visch MB, Dompeling E, Van Weel C, Van Herwaarden CLA. Increased bronchial hyperresponsiveness after inhaling salbutamol during 1 year is not caused by subsensitization to salbutamol. $J$ Allergy Clin Immunol 1990;86:793-800.

21 Dahl R, Johansson SA. Effect on lung function of budesonide by inhalation, terbutaline s.c. and placebo given simultaneously or as single treatments. Eur J Respir Dis 1982;122(suppl):132-7.

22 Tattersfield AE, Britton JR. Beta-adrenoceptor agonists. In: Barnes PJ, Rodger IW, Thomson NC, eds. Asthma: basic mechanisms and clinical management. New York: Academic Press, 1988:563-90.

23 Ellul-Micallef $R$, Fenech FF. Effect of intravenous prednisolone in asthmatics with diminished adrenergic responsiveness. Lancet 1975;ii:1269-71.

24 Arnoud A, Vervlock D, Dugue P, Orehek J, Charpin J. Treatment of acute asthma: Effect of intravenous corticosteroids and beta $_{2}$-adrenergic agonists. Lung 1979; 156:43-8.

25 Turner-Warwick M. Epidemiology of nocturnal asthma. Am J Med 1988;85:6-8.

26 Barnes PJ. Nocturnal asthma: mechanisms and treatment. $B M J$ 1984;288:1397-8.

27 Horn CR, Clark TJH, Cochrane GM. Inhaled therapy reduces morning dips in asthma. Lancet 1984; i:1143-5.

28 Dahl R, Pedersen B, Hagglof B. Nocturnal asthma: Effect of treatment with oral sustained-release terbutaline, inhaled budesonide, and the two in combination. J Allergy Clin Immunol 1989;73:811-5.

29 Connolly CK. Diurnal rhythms in airway obstruction. $\mathrm{Br} J$ Dis Chest 1979;73:357-66.

30 Reinhardt D, Schuhmacher P, Fox A, Stemmann EA, Wegner F. Comparison of the effects of theophylline, prednisolone and sleep withdrawal on airway obstruction and urinary cyclic AMP/cyclic GMP excretion of asthmatic children with and without nocturnal asthma. Int $J$ matic children with and without nocturnal ast

31 Van Aalderen WMC, Postma DS, Koëter GH, Knol K. The effect of reduction of maintenance treatment on circadian variation in peak expiratory flow rates values in asthmatic children. Acta Paediatr Scand 1988;77:269-74.

32 Hetzel MR, Clark TJH, Houston K. Physiological patterns in early morning asthma. Thorax 1977;32:418-23.

33 Ryan G, Latimer KM, Dolovich J, Hargreave FE. Bronchial responsiveness to histamine: relationship to diurnal variation of peak flow rate, improvement after bronchodilator, and airway calibre. Thorax 1982;37:423-9. 